\title{
Age related variations of serum concentrations of normally occurring IgG antibodies to Clostridium perfringens
}

\author{
EVA ZARÉN,* ANNA SCHWAN, * B FRENCKNER \\ From the *Institute of Clinical Bacteriology, University of Uppsala, Sweden, and the Department of Paediatric \\ Surgery, St Göran's hospital, Karolinska Institute, Stockholm, Sweden
}

SUMMARY In studies using indirect immunofluorescence IgG antibodies to Clostridium perfringens were found in sera from healthy adults. Sera from 236 healthy children were examined. The normally occurring IgG antibodies to $C$ perfringens were found to have an age related variation. Preliminary data suggest that they are not correlated to $C$ perfringens $\alpha$ toxin. The antigen(s) against which the antibodies are directed is/are probably part of the cell wall, but its/their exact nature is not known.

Clostridium perfringens is part of the normal intestinal flora in man and animals and also occurs widely in soil. ${ }^{1}$ It is the most commonly found Clostridium in clinical specimens. ${ }^{2}{ }^{3} C$ perfringens can be associated with severe puerperal and post-abortal uterine infection. It can also cause gas gangrene, an invasive infection with high mortality; less dangerous is anaerobic cellulitis, in which the clostridial infection is limited to areas of necrotic tissue. ${ }^{1}$ When isolated from a surgical wound, its clinical importance can be minimalthat is, it represents contamination rather than infection. ${ }^{45}$ The environment of the infection site undoubtedly influences the severity of the infection.

$C$ perfringens enterotoxin, which is produced at the time of sporulation, is a well known cause of food poisoning. Haemagglutination antibodies to the enterotoxin of $C$ perfringens are present in most normal sera. ${ }^{6}$ Most strains of $C$ perfringens produce $\alpha$ toxin, a haemolysin responsible for the intravascular haemolysis, coagulation disorder, and capillary damage seen in severe $C$ perfringens infection. Antibodies to the $\alpha$ toxin of $C$ perfringens have been found in sera from patients with rheumatoid arthritis but not in sera from healthy subjects. ${ }^{7}$

In studies of the immune response to anaerobic bacteria, using indirect immunofluorescence, we showed high IgG antibody titres to $C$ perfringens, not only in paired sera from patients infected with $C$ perfringens, but also in all sera from blood donors and other healthy subjects. ${ }^{89}$ Further studies were sub-

Accepted for publication 6 October 1986 sequently undertaken to elucidate this phenomenon. Sera from healthy children were analysed by indirect immunofluorescence for IgG antibodies to whole cell antigens of $C$ perfringens.

\section{Material and methods}

BACTERIAL STRAINS

Three strains of $C$ perfringens were used as antigen. Two strains (1073 and 1120) were isolated from wounds and one (1069) from faeces. The strains were grown on blood agar plates supplemented with haemin and vitamin $\mathrm{K}$ using a Whitley anaerobic cabinet (Don Whitley Scientific Ltd, Shipley, West Yorkshire, England). The strains were identified according to the directions outlined by Holdeman et al, ${ }^{10}$ with the use of the API 20 A (API, Plainview, New York, USA) and the Minitek (BBL Laboratories, Cockeysville, Maryland, USA) tests.

\section{SER UM SAMPLES}

Sera were collected from 236 children aged 0-15 years. The children underwent surgery at St Göran's children's hospital, Stockholm, because of minor surgical disorders (hernia, circumcision etc) or minor trauma. Children with a history of malignant disease, allergic disorder, present or recent infectious desease, immunodeficiency or extensive malformations were not included. The sera were frozen in small portions at $-20^{\circ} \mathrm{C}$ until used. The sera were divided into age groups (table 1). Exclusively breast fed infants were present only in the youngest age groups. In the group 
of infants up to 1 month old, five of six were breast fed; $>1-2$ months, six of seven; $>2-3$ months, six of 11 ; > 3-4 months, eight of nine; $>4-5$ months, one of four; and > 5-6 months, one of six. No child over the age of 6 months was breast fed. Sera from 12 healthy adults (seven women, five men) aged 18-37 years were also examined.

\section{PREPARATION OF ANTIGENS}

The bacteria were grown on solid media as described above and harvested in sterile $0 \cdot 15 \mathrm{M}$ sodium chloride after 48 hours. The cells were washed three times and resuspended in phosphate buffered saline (PBS) $\mathrm{pH}$ $7 \cdot 2$, to a concentration of about $10^{8}$ cells $/ \mathrm{ml}$. Glass slides with circular areas of $50.2 \mathrm{~mm}^{2}$ (Novakemi AB, Sweden) were used for smears, on to which $0.01 \mathrm{ml}$ bacterial suspension was smeared. The slides were air dried and stored at $-20^{\circ} \mathrm{C}$ until use.

INDIRECT IMMUNOFLUORESCENCE TESTS

Serum samples were diluted $1 / 10$ to $1 / 1280$ in twofold increments in PBS containing 4\% bovine serum albu$\min ; 0.01 \mathrm{ml}$ of each dilution was allowed to react for 30 minutes with the bacteria on the slides, which were incubated in a moist chamber at $37^{\circ} \mathrm{C}$. After washing in PBS for 10 minutes $0.01 \mathrm{ml}$ of fluorescein isothiocyanate (FITC) labelled antihuman IgG (Dako immunoglobulins, Copenhagen, Denmark) was added to each smear, incubated at $37^{\circ} \mathrm{C}$ for 30 minutes, and washed with PBS as above. The conjugate had a molar F:P ratio of 2:3 and was diluted $1 / 30$ in PBS. The working dilution was determined by chess board titration. The slides were mounted under a cover glass with phosphate buffered glycerin. The preparations were read under a Zeiss standard 14 fluorescence microscope equipped with incident light using narrow blue band activation and an LP 520 as a secondary filter. The lamp was an Osram HBO 50 mercury lamp and the objective a planapochromate $100 / 1 \cdot 25$. The criteria for recording the specific staining of the bacteria were as follows: $3+=$ intensely fluorescent margins, well marked edges; $2+=$ faintly fluorescent margins, edges usually well marked; $1+$ = barely distinguishable fluorescent margins, diffuse edges; $3+$ and $2+$ were regarded as positive reactions, $1+$ and no visible bacteria as negative reactions. Controls with smears stained with the conjugate only were included.

\section{STA TISTICS}

The significance of differences in antibody titres in sera from boys compared with those found in sera from girls as well as in sera from breast fed and nonbreast fed infants was assessed with a standard Student's $t$ test. We also repeated the statistical analysis with a non-parametric procedure (Wilcoxon rank sum test) as the antibody titre was a variable with a skewed distribution. ${ }^{11}$

\section{HAEMOLYSIN EXPERIMENTS}

Demonstration of haemolysin The $C$ perfringens strains were grown in chopped meat broth for 48 hours at $37^{\circ} \mathrm{C}$. The culture supernatant was sterilised by filtration through a Millipore filter $45 \mu \mathrm{m}$ (Millipore SA, Molsheim, France). Filtrate $(20 \mu \mathrm{l})$ was carefully applied to an agar plate with $5 \%$ washed sheep blood. The plates were incubated at $37^{\circ} \mathrm{C}$ for five hours and at $4^{\circ} \mathrm{C}$ overnight. A distinct haemolytic zone was seen the next day.

Serum samples Sera were inactivated at $56^{\circ} \mathrm{C}$ for 30 minutes. The experiments were performed with inactivated as well as with activated serum. Serum lipoproteins were precipitated by mixing $0.5 \mathrm{ml}$ serum with a mixture of $0.05 \mathrm{ml}$ dextran sulphate, $0.1 \mathrm{ml} 1 \mathrm{M}$ $\mathrm{CaCl}_{2}$, and $0.35 \mathrm{ml}$ distilled water at $4^{\circ} \mathrm{C}$ for 40 minutes. ${ }^{12}$

Influence of serum on haemolysin activity The filtrate of $C$ perfringens broth culture was mixed $1 / 1$ with serum with a high and a low immunofluorescence titre against $C$ perfringens whole cell antigen, respectively. Final serum titres were $1 / 10,1 / 20$, and $1 / 40$. The mixture was incubated at $37^{\circ} \mathrm{C}$ for 30 minutes. Samples from the various dilutions were applied on blood agar plates that were incubated as above. Untreated culture filtrate diluted $1 / 1$ in PBS was used as control. The diameters of the haemolytic zones were compared.

\section{Results}

\section{IMMUNOFLUORESCENCE TESTS}

All children had acquired antibodies against $C$ perfringens by the age of 15 months, and the titres were found to increase with age. The figure shows the immunofluorescence IgG antibody titres against one $C$ perfringens strain. The pattern was the same for the other two strains. Values within some age groups were widely scattered, with occasional very high titres. No significant differences were observed between titres found in sera from boys compared with those found in sera from girls, in the different age groups or as a whole. There were no significant differences in titres between sera from breast fed compared with nonbreast fed infants.

\section{HAEMOLYSIN EXPERIMENTS}

No difference was observed between the haemolytic zones produced by $C$ perfringens culture filtrate mixed with serum with a high immunofluorescence antibody titre against $C$ perfringens compared with filtrate 


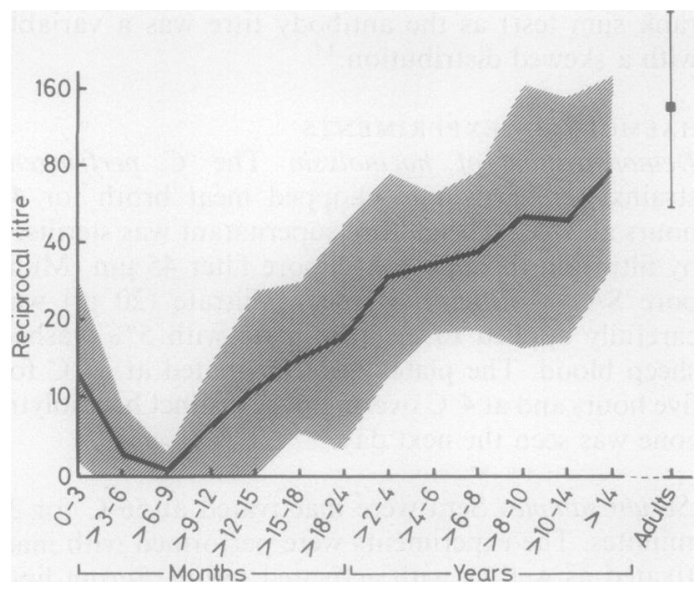

Mean IgG antibody titres in sera from various age groups against Clostridium perfringens strain 1073. Shadowed area indicates standard deviation. Pattern was identical for all strains studied.

mixed with serum with a low immunofluorescence antibody titre against $C$ perfringens, nor was there any difference between those two zones and the control. Inactivated and activated serum gave the same results.

\section{Discussion}

IgG antibodies to antigens of whole cells of $C$ perfringens were found in sera from healthy children, which is in accordance with our findings in healthy adults, ${ }^{9}$ as well as with the reports of other workers (Danielsson D, personal communication). The titres of the antibodies show an age related variation similar to that of normally occurring antibodies to other bacterial antigens like staphylococci, ${ }^{13}$ Haemophilus influenzae, ${ }^{14}$ and Escherichia coli. ${ }^{15}$ When the amount of maternal IgG antibodies decreases the titres are very low. They show a gradual increase with increasing age, probably as the result of the immune

Table Age groups and No of children per age group

\begin{tabular}{llll}
\hline Age & Total No & Boys & Girls \\
\hline Months & & & \\
$0-3$ & 24 & 18 & 6 \\
$>3-6$ & 19 & 15 & 4 \\
$>6-9$ & 18 & 13 & 5 \\
$>9-12$ & 19 & 19 & \\
$>12-15$ & 14 & 11 & 3 \\
$>15-18$ & 13 & 10 & 3 \\
$>18-24$ & 16 & 14 & 2 \\
Years & 17 & 12 & 5 \\
$>2-4$ & 19 & 14 & 5 \\
$>4-6$ & 12 & 10 & 2 \\
$>6-8$ & 17 & 14 & 3 \\
$>8-10$ & 34 & 28 & 6 \\
$>10-14$ & 14 & 9 & 5 \\
$>14-15$ & & & \\
\hline
\end{tabular}

system being repeatedly exposed to the antigens of $C$ perfringens, which is present in the normal intestinal flora as well as in the environment.

The breast feeding rate might possibly be correlated to the serum antibody titres. During the first months of life almost all Swedish infants are breast fed, while at the age of 6 months or more all have artificial feeding added to the diet. As the titres were all quite low in the age groups up to 6 months, no definite conclusions can be drawn. The question of a possible correlation between breast feeding and serum antibody titres to $C$ perfringens is interesting but cannot be answered by analysing our results.

The titres agains $C$ perfringens shown in this study are lower than those found in an earlier study of 56 blood donor sera. ${ }^{9}$ There are several possible explanations for this. Firstly, the three $C$ perfringens strains used in this study may have differed antigenically from the strain used earlier. Secondly, the FITCconjugated rabbit antihuman IgG, although obtained from the same manufacturer, was not standardised identically in the two studies.

We cannot tell against which antigen(s) the antibodies shown by immunofluorescence are primarily directed. $C$ perfringens cells are known to produce several exotoxins to which the immune system might be exposed. Haemolysin assays designed to detect antibodies to $C$ perfringens $\alpha$ toxin were, however, negative. Since we used whole bacterial cells in our immunofluorescence tests it seems reasonable to believe that the antibodies are directed against components of the cell wall. The possibility that they are due to a cross reaction with some other bacterial antigens cannot be excluded. The results show, however, that they are not caused by non-specific binding of IgG to the $C$ perfringens cell wall similar to that which occurs with protein A of staphylococcal cells. This confirms the results of earlier absorption experiments. ${ }^{5}$

Smith ${ }^{1}$ points out that in spite of its high incidence $C$ perfringens surprisingly seldom gives rise to severe infections. It is tempting to speculate that the normally occurring IgG antibodies might be protective to some extent against the invasion of $C$ perfringens.

We have only studied the incidence of IgG antibodies to $C$ perfringens, but information on IgM antibodies would be of interest to elucidate the role of the immune system. Further studies are needed to clarify the clinical importance of the IgG antibodies shown in this study.

We thank Professor Dan Danielsson for constructive discussions and critical reading of the manuscript, Professor Roland Möllby for valuable advice on the haemolysin experiments, Mrs Ulla Zettersten for skilful technical help, the staff at the department of pae- 
diatric anaesthesia and the paediatric chemistry laboratory, St Göran's hospital, for their help in collecting the serum specimens.

\section{References}

1 Smith LDS. The pathogenic anaerobic bacteria. Springfield, Illinois: Charles C Thomas, 1975.

2 Holland JW, Hill BO, Altemeier WA. Numbers and types of anaerobic bacteria isolated from clinical specimens since 1960 J Clin Microbiol 1977;5:20-5.

3 Moore WEC, Cato EP, Holdeman LV. Anaerobic bacteria of the gastrointestinal flora and their occurrence in clinical infections. J Infect Dis 1969;119:641-9.

4 Bornstein DL, Weinberg AN, Swartz MN. Anaerobic infections, review of current experience. Medicine 1964;43:207-32.

5 Schwan A. Immune response to anaerobic bacteria. Antibody production in human infection and experimental studies with Bacteroides fragilis. Uppsala: Uppsala university, 1981. (Thesis.)

6 Uemura T, Genigiorgis C, Rieman HP, Franti CF. Antibody against Clostridium perfringens type $\mathrm{A}$ enterotoxin in human sera. Infect Immun 1974;9:470-1.

7 Månsson I, Olhagen B. Intestinal Clostridium perfringens in rheumatoid arthritis and other connective tissue disorders. Acta Rheumatol Scand 1966;12:167-74.

8 Schwan A, Rydén AC. The clinical importance of anaerobic bac- teria in wound infections after gastrointestinal surgery. Scand $J$ Infect Dis 1978;10:119-25.

9 Schwan A. IgG antibodies against anaerobic bacteria in blood donor sera. J Clin Pathol 1981;34:416-9.

10 Holdeman LV, Cato EP, Moore WEC. Anaerobe laboratory manual. Blacksburg, Virginia: Virginia Polytechnic Institute and State University, 1977.

11. Colton T. Statistics in medicine. Boston: Little, Brown \& Company, 1974.

12 Winblad S. Studies on non-specific antistreptolysin O titre. 1. The influence of serum $\beta$-lipoproteins on the non-specific antistreptolysin $O$ titre. Acta Pathol Microbiol Scand 1966;66:93-104.

13 Granström M, Julander IG, Hedström SÅ, Möllby R. Enzymelinked immunosorbent assay for antibodies against teichoic acid in patients with staphylococcal infections. J Clin Microbiol 1983;17:640-6.

14 Dahlberg T. Quantitation of antibodies to Haemophilus influenzae type $B$ in humans by enzyme-linked immunosorbent assay. J Clin Microbiol 1981;13:1080-7.

15 Cohen IR, Norins LC. Natural human antibodies to gramnegative bacteria. Immunoglobulins $G, A$, and $M$. Science 1966;152:1257-9.

Requests for reprints to: Dr Eva Zarén, Institute of Clinical Bacteriology, University of Uppsala, Box 552, 5-751 22 Uppsala, Sweden. 